\title{
Kaźmierz Karłowski
}

Procedura w sprawach z tytułu impotencji i amencji w razie braku ekspertyzy, jeśli strona uchyla się od zeznań i ekspertyzy

Prawo Kanoniczne : kwartalnik prawno-historyczny 3/1-2, 195-214

1960

Artykuł został zdigitalizowany i opracowany do udostępnienia w internecie przez Muzeum Historii Polski w ramach prac podejmowanych na rzecz zapewnienia otwartego, powszechnego i trwałego dostępu do polskiego dorobku naukowego i kulturalnego. Artykuł jest umieszczony w kolekcji cyfrowej bazhum.muzhp.pl, gromadzącej zawartość polskich czasopism humanistycznych i społecznych.

Tekst jest udostępniony do wykorzystania w ramach dozwolonego użytku. 
KS. KAZMIERZ K A R E O W S I

\section{PROCEDURA W SPRAWACH $Z$ TYTUEU IMPOTENCJI I AMENCJI W RAZIE BRAKU EKSPERTYZY, JES̄LI STRO- NA UCHYLA SIE OD ZEZNAN I EKSPERTYZY*)}

Przyjęta jest powszechnie zasada, którą zwięźle wypowiada Cappello (De matr. 6 inr 883): „Media probandi (in processibus de vinculo matrimonii) sunt: confessio partium, testes, instrumenta, depositiones peritorum".

Kard. Gasparri (De matr. II. nr. 1277) zaznacza, że obecnie iure Codicis przeprowadza sie procesy de probanda impotentia antecedente et perpetua na podstawie: depositionis iuratae partium, iurati testimonii septimae manus, et inspectionis corporum, in qua servari debet, quoad substantiam norma tradita a S.C.C. in Instructione Bened. XIV. „Dei miseratione" et a Regulis S.C.C. de Sacramentis, i dodaje: "secus acta processus nullitate laborarent". Również gdy chodzi o proces de defectu consensus ob a ment i a m podaje Kard. Gasparri (l.c. nr. 1279)", ,p e r it or u m suffragium requirendum est" i to "zgodnie z przepisem can. 1982, który opiewa: ,requiratur suffragium peritorum, qui infirmum, si casus ferat, eiusve acta quae amentiae suspicionem ingerunt, examinent..."

To też art. 138 Instrukcji S.C.S. Provida z 15.8.1936 r. żąda: "In causis impotentiae et defectus consensus ob - amentiam requirendum est suffragium peritorum" (can. 1976-1982).

Rzecz jest jasna, skoro ma się na uwadze, że najczęściej w wypadkach tak impotencji jak i amencji suffragium perito-

* Referat wygłoszony na Zjeździe XX Oficjałów w Warszawie dnia 18.IX.1957 r. 
rum jest jednym $z$ głównych środków dowodowych (medium probandi).

Sędzia musi dojść do moralnej pewności o stanie faktycznym sprawy, zanim wyda wyrok pozytywny, a jednym $z$ walnych środków do wytworzenia sobie tej pewności moralnej to właśnie: suffragium peritorum, gdy chodzi o tytuł impotencji i amencji.

O konieczności wytworzenia sobie pewności moralnej przez sędziego, zanim przystąpi do wydania wyroku pozytywnego, obszernie i znamiennie wypowiedzial się Ojciec św. Pius XII. w swej alokucji z dnia 1.10.1942 r., wygłoszonej do Audytorów Roty Rzymskiej.

Moralna pewność z pozytywnego punktu widzenia ma tę właściwość, że wyklucza wszelką uzasadnioną wątpliwość (,excludit omne dubium fundatum seu prudens”) i różni się od zwykłego prawdopodobieństwa zwanego quasi -- certitudo. Ujmując moralną pewność z negatywnego punktu widzenia dopuszcza ona ,absolutam possibilitatem contrarii" i pod tym względem różni się od pewności a b solutnej (certitudo absoluta), ,in qua omne possibile dubium circa veritatem facti et non - existentiam contrarii est totaliter exclusum". - Otóż powiada papież, że pewność moralna jest konieczną i wystarczającą dla wydania wyroku.

Pewność moralna jest pewnością obiektywną (certitudo obiectiva); opiera się na motywach obiektywnych (innitens rationibus obiectivis). Wymagane sa , determinatae probationes vel corroborationes probationum". By zapewnić obiektywną wartość tej pewności, ustawodawca ustalił zasady jasno sprecyzowane co do przeprowadzenia dochodzeń i co do udowadniania; oraz ustanowił poszczególne urzędy (officia) i osoby (personas), które $w$ toku procesu sprawują funkcję swe $w$ taki sposób, by miały przed oczyma określone prawa lub fakty i je stwierdzały oraz ich bronily. Nie jest to nic innego - powiada papież - jak słuszny kult, czyli troska o zachowanie prawa formalnego.

Jednak, - dodał papież, - ścisłe zachowanie tych norm prawnych nie jest celem samym $w$ sobie, lecz zasady te są je- 
dynie środkiem prowadzącym do celu, by uzyskać i zapewnić pewność moralną, opartą obiektywnie na rzeczywistości faktu. Nie powinna się więc zdarzyć taka ewentualność, by to: „quod volente legislatore esse debet a diutorium a c cautio ad inveniendam veritatem, opposita ratione fiat impedimentum". I dodaje papież b. znamienne słowa: „Quando autem accidit, ut observantia iuris formalis vertatur in iniustitiam et defectum aequitatis, semper possibilis est recursus ad legislatorem".

W najnowszej procedurze sądowniczej (recentiore actione iuridica) kościelnej - powiada papież: — ,non primo in loco positum sit principium procedendi secundum formulas iuridicas, sed axioma liberae diiudicationis probationum". Zadaniem sędziego jest - powiada papież — bez uszczerbku dla przepisów normujących przewód sądowy ,decidere secundum propriam scientiam atque conscientiam", utrum demonstrationes allatae et inquisitiones ordinatae sulficiant necne tzn. czy nagromadzone dowody wystarczają dla wytworzenia nieodzownej pewności moralnej i dla stwierdzenia prawdziwego i rzeczywistego stanu rzeczy, które ma być przedmiotem wyroku. Otóz to jest zasada pierwszorzędnej wagi, wypowiedziana przez samego papieża.

Mając na oku tę podstawową zasadę, wypowiedzianą przez Ojca św., należy rozstrzygnąc nasze zagadnienie, gdy w wypadku impotencji wzgl. amencji odnośna strona uchyla się od poddania się ekspertyzie lekarskiej i od złożenia zeznań.

Naipierw, jeśli chodzi o tytul a men c j i mamy rozporządzenie art. 151 Instr. S.C.S. z 15.8.1936, które opiewa, że w danym razie można się zadowolić ekspertyza przeprowadzona przez tylko jedne g o lekarza. Jedynie w trudniejszych przypadkach („pro casus gravitate") winni przeprowadzić badania dwaj lekarze - biegli. (por. Jone ${ }^{2}$ II. s. 292 ad can. 1982 „Duo periti solummodo in casibus difficilioribus").

To jest reguła naczelna, która w zwykłych wypadkach ma mieć zastosowanie. Na ogół nie przedstawia obecnie poważniejszych trudności fakt przebywania strony chorej $\mathrm{w}$ zakładzie 
psychiatrycznym, ponieważ istnieje na ogół możliwość poddania jej badaniu lekarskiemu przez lekarza wzgl. przez lekarzy zakładowych. W wyrokach Roty z r. 1943 mamy dwa wypadki, gdzie ekspertyze przeprowadził ex offo jako biegły lekarz zakładu, oraz inny biegły wzgl. biegli wydali orzeczenie na podstawie akt sprawy. (Dec. 82 i dec. 87 r. 1943) Gdy jednak strona przebywa już poza zalkładem na w ol nej stopie $i$ wzbrania się poddać ekspertyzie, - jak wtedy sprawa się ma?

Odpowiedzmy wpierw na pytanie, czy istnieje teoretycznie możliwość zestawienia materiału dowodowego w wypadku amencji w tej mierze, by bez przeprowad zen i a ekspertyzy lekarskiej sprawa była dojrzała do wydania wyroku ewent. stwierdzającego nieważność małżeństwa z tytułu amencji? - Nie może co do tego być wątpliwości, skoro Rota Rzymska: 23.III.1914 r. coram Sabastianeli (Dec. Rot. 1914. Dec. XII. p. 142) wydała wyrok pozytywny bez poddania strony ekspertyzie lekarskiej. Zresztą z samego tekstu can. 1982 wynika to jasno; kanon ten bowiem zawiera słowa: iż strona obciążona amencją, ma być poddana oględzinom lekarskim, jednak z dodaniem zastrzeżenia: „si casus ferat”. Przewiduje więc Kodeks takie wypadki, w których ekspertyza lekarska nie będzie możliwa lub celowa, a więc wypadki, w których będzie trzeba zadowolić się tylko zbadaniem a k t przez lekarzybiegłych, w których to aktach znajdować się powinny wszelkie możliwe zaświadczenia lekarzy oraz opis choroby z zakładu, odnośnie choroby umysłowej strony oraz ewent. zeznania tych lekarzy, którzy prywatnie leczyli stronę, a którzy to lekarze występują w charakterze świadków sprawy.

Wypadek, o którym wspomniałem, który w r. 1914 rozstrzygnęła św. Rota pozytywnie był następujący. Z góry zaznaczam, że wtedy tj. przed Kodeksem nie bylo jeszcze przepisu żądającego ekspertyzy lekarskiej.

Powód imieniem Nuntius popadł $\mathrm{w}$ chorobę (in gravissimum morbum incidit) zwaną ileo - tifo i zawarł ślub ,in morbi stadio accutissimo" z Julią. Powróciwszy do zdrowia żył Nuntius ponad jeden rok z żoną Julią" signa mutui amoris sibimet comunicantes". Potem zaczęła się niezgoda między Julią 
a teściami jej. Julia opuściła męża, wróciła do swych rodziców i wkrótce związała się $z$ innym mężczyzną. Powód wniósł skargę - było to w 2 lata po zawarciu ślubu, - do Sądu Diecezjalnego uzyskując wyrok za nieważnością. W instancji apelacyjnej rozpatrzyla ten wyrok Rota Rzymska i wyrok ten potwierdziła.

Jakich dostarczył powód dowodów, na których św. Rota oparła swój wyrok? Powód dostarczył declarationes medicorum, u których się leczył w czasie choroby przed ślubem. Obydwaj lekarze poświadczyli, że Nuntius w grudniu $1905 \mathrm{r}$. chorował na chorobę, którą nazwali ,ileo tifo powodująca u powoda "un stato continuo di subdelirio con allucinazioni" (ślub odbył się 5.1.1906). To świadectwo lekarskie przyjęla św. Rota, mimo ze lekarze nie zostali wezwani „ad exactius morbi indolem, initium, progressum ac periodum acutam designandam, nec non ad declarationem scripto datam elucidandam, iuramentoque vallandam", a to dlatego ponieważ obydwaj należeli do sekty masońskiej. Mimo to stanęła Rota na stanowisku, że na wiarę zasługuje ich ,attestatio propria manu subscripta, quae plenam fidem mereri dicenda est". Sw. Rota dodała, że znana jest zasada prawa: ,scitum in iure est iudicio peritorum in arte esse deferendum". Sw. Rota przyjęła orzeczenie tych lekarzy (chociaż nie było zaprzysiężone), ponieważ jak $\mathrm{w}$ tekście wyroku zaznaczono, zgodne ono było z zeznaniami świadków, którzy przy zawieraniu ślubu byli obecni i potwierdzili uwidaczniający się wtedy stan choroby powoda. Niemniej oparła się św. Rota w swym wyroku na wywodzie teoretycznym autora psychiatry El. Lucatello dotyczącym tego rodzaju chorób (febres tiphosae), który pozytywnie wykłada, że ten rodzaj choroby in stadio acuto powoduje delirium lub quasi - delirium, nimiam debilitatem i to $\mathrm{w}$ takim stopniu, że „mentem perturbant ut aegrotantem nec reddit sui cumpotem, neque liberum".

Tak więc caly material dowodowy dla tego wyroku św. Roty składal się: z zeznania powoda, następnie z zeznań świadków podanych przez powoda, potwierdzających jego stan choroby $w$ chwili zawierania ślubu oraz $z$ pisemnego po- 
świadczenia dwóch lekarzy, którzy leczyli powoda przed zawarciem ślubu, o czym co dopiero mówiłem. Zeznania pozwanej i jej matki, jako osób obciążonych ,per corruptos mores", nie uznano za wiarogodne; zeznania te przeciwstawialy się tezie powództwa.

W procesie tym nie przeprowadzili więc lekarze-biegli żadnej ekspertyzy lekarskiej, ani nie badali akt sprawy. Powoda nie badali lekarze-biegli, niewątpliwie $z$ tego powodu, że w czasie prowadzenia procesu powód był już zupełnie zdrowym człowiekiem. Od 4 lutego $1908 \mathrm{r}$. bowiem, a więc $w$ dwa lata po ślubie, służył już w wojsku. Mimo to św. Rota wydała wyrok, iż małżeństwo zawarto nieważnie $z$ tytułu amencji, doszedłszy do pewności moralnej $w$ danej sprawie.

$\mathrm{Na}$ ogół obecnie po wydaniu Kodeksu i Instrukcji S.C.S. $\mathrm{z}$ dnia 15.8.1936 r. można stanąć na stanowisku, że jeśli strona, która $w$ czasie zawierania ślubu była obciążona chorobą umysłowa, a obecnie już od kilku lat po ślubie uchodzi za uleczoną, gdyż np. pracuje na swe utrzymanie, nie ma konieczności poddawania jej oględzinom lekarskim przez lekarzybiegłych. To też $w$ takich wypadkach, choćby strona ta nawet nie chciała składać zeznania sądowego, istnieje możliwość przeprowadzenia dowodu dla wydania ewent. pozytywnego wyroku. Należałoby wtedy postarać się o świadectwa lekarzy i zakładów, w których wzgl. u których ewent. przed ślubem strona się leczyła, oraz należałoby powołać jednego lub dwóch lekarzy-biegłych, którzy wydać winni swe orzeczenie na podstwaie nagromadzonego materiału dowodowego, a więc na podstawie akt sąłowych, do czego należą oczywiście także zeznania strony powodowej i świadków.

O ile natomiast strona pozwana tj. obciążona chorobą umysłową obecnie przebywa $\mathrm{w}$ zakładzie psychiastrycznym, natenczas nie ma na ogół większych trudności — jak już wspomniałem - poddania jej ekspertyzie lekarskiej przez dwóch lekarzy - biegłych spośród lekarzy odnośnego zakładu. Gdyby to ostatnie nie było możliwe $z$ jakichkolwiek powodów, wystarczałoby, by pobrano $z$ zakładu psychiatrycznego poświad- 
czenia, a lekarzom-biegłym, ex offo powołanym, przedstawionoby materiał downodowy zawarty $w$ aktach.

W wyrokach Roty Rzym. znajdują się wyroki pozytywne, których materiał dowodowy stanowiły orzeczenia biegłych, wydane tylko na podstawie alkt sprawy, - tak iż biegli nie przeprowadzali inspectionem corporis danej osoby - oraz poświadczenia wzgl. zeznania lekarzy zakładowych i zeznania świadków i strony powodowej. (Dec. Rot. 1945 dec. 26 i 1940 dec. 56).

Nawet mógłby zajść wypadek, że kontrahent wzbraniający się poddać ekspertyzie lekarskiej i wzbraniający się złożyć zeznanie, nie leczyl się wogóle ani przed ani po ślubie $w$ zakladzie psychiatrycznym lub u lekarzy prywatnych; mimo to istniałaby możliwość przeprowadzenia dowodu istnienia amencji $w$ chwili ślubu. Jednakowoż byloby to tylko wtedy możliwe, gdyby za pomocą zeznań strony powodowej i kilku wiarogodnych świadków, można było ustalić charakterystyczne objawy danej choroby umysłowej w czasie zawierania ślubu i gdyby na podstawie tych danych powolany lekarz-biegły wzgl. dwaj lekarze biegli stwierdzili rodzaj i stopień odnośnej choroby.

Otóż da się pomyśleć np. wypadek, że w danym razie choroba umysłowa wybuchła nagle i niespodzianie i uwydatnily sie charakterystyczne objawy tej choroby. Swiadkiem mógł być $w$ danym wypadku lekarz, którego przywołano do pomocy, prócz tego mogli być świadkami inni ludzie np. domownicy. Gdy więc zawarto małżenstwo w okresie, w którym działanie ujemne tej choroby mogło dać się we znaki, istniałaby możliwość przeprowadzenia dowodu, chociażby później, - gdy proces, się toczy, - strona, która dotknięta była tą chorobą, nie chciała złożyć zeznania i poddać się badaniu przez lekarzybiegłych. Wystarczającym dowodem mogło by być zeznanie lekarza-świadka, innych naocznych świadków i strony pow:dowej oraz orzeczenie lekarzy-biegłych, którym należałoby przedstawić do oceny wlaśnie wymieniony materiał zestawiony w aktach. 
Zależy więc wszystko ostatecznie od wyrobienia sobie przekonania o sprawie przez Trybunał, który swój sąd wyrobi sobie na podstawie całolsształtu materiału dowodowego i ewent. dojdzie do moralnej pewności, czy dowód wystarczający dostarczono, czy też nie.

Cały punkt ciężkości dowodzenia kocentrować się będzie na stwierdzeniu: $w$ jakim stanie znajdowal się chory $w$ chwili zawierania małżeństwa, czy więc miał dostateczny stopień rozeznania. Do tego zmierzają wszelkie dochodzenia przewodu sądowego, by Trybunał mógł sobie wyrobić pewność moralną co do stanu rzeczy.

Powiada św. Rota w wyroku z dnia 7.12 .1946 r. cor. Wynen (Dec. Rot. 1946 dec. 58 str. 572 n. 3), że są choroby umysłowe, które od małych zaczątków rozwijają się powoli, aż dochodzą „ad conclamatam insaniam" (do wyraźnej i pełnej amencji); natomiast inne choroby umysỉowe, przeważnie bez stadium poprzedzającego wybuchają nagle i niespodzianie; prócz tego powiada ten wyrok - sa choroby umysłowe, które dopuszczaja ,remisię", i jeśli ta remisia trwa długo ,aegrotus iterum fit dominus suonum actuum"; są także - powiada św. Rota, choroby umysłowe, które mogą być całkowicie uleczone (,qui perfecte sanari possunt"), a w takim wypadku należy stwierdzić, w jakim stopniu w chwili zawierania małżeństwa choroba została uleczona. Oczywistą jest rzeczą, powiada św. Rota, że sędzia duchowny, który nie jest psychiatrią na ogół zawsze (quasi semper) winien posługiwać się pomocą fachową lekarzybiegłych, ażeby stwierdzoną została „,natura morbi mentalis" w danym wypadku i by określono, w jakim stanie umysłowym znajdował się kontrahent $\mathrm{w}$ czasie zawierania małżenstwa. Sędzia jednak - dodaje Rota, - powinien: ,praeter vota peritorum" "cetera quoque causae adiuncta" attente perpendere (can. $1804 \S 1$ ), et in reddendis rationibus decidendi exprimere debet quibus motus argumentis peritorum conclusiones aut admiserit aut reiecerit". (can. $1804 \S 2$ ).

Co do oceny orzeczeń wydanych przez lekarzy-biegłych da se ś. Rota następującą zasadę: „Iudex non tantum eorum (peritorium) conclusiones, etsi concordes, sed cetera 
quoque causae adiuncta attente perpendere debet (can. 1804) et sedulo considerare, an facta quibus peritiae nituntur vera sint et iuridice probata, et conclusiones logice e praemissis sequantur". (Dec. Rot. r. 1946 dec. 26 nr 9. cor. Heard). Sędzia więc dopiero wtedy przyjąc może jako jedną $z$ podstaw, na której oprze swój wyrok, orzeczenie biegłych, jeśli stwierdził, że fakty, z których biegli wywnioskowują swe twierdzenia są prawdziwe i dostatecznie udowodnione, oraz jeśli wnioski lekarzy-biegłych wynikają logicznie z przesłanek (por. Dec. Rot. 1944 dec. 38 nr 5 cor. Teodori).

Należy, zaznaczyć, że św. Rota w wyroku z dnia $16.7 .1910 \mathrm{r}$. cor. Prior (Dec. Rot. r. 1910 dec. 27 nr 10) stwierdziła, iż przeprowadzenie dowodu na istnienie amencji w chwili zawierania ślubu nie jest nawet wtedy wykluczone, gdy lekarze-biegli w swych wotach wzajemnie sprzeciwiają się sobie: ,peritis inter se dissentientibus non illico concludendum est rem non probari". (Oesterle, Ephemer. Iur. Can. 1955, 295).

Rota Rzymska jeszcze nie tak dawno, bo w wyrokach z r. 1913 (13.2.1913; 11.8.1913) i r. 1915 (15.5.1915) podawała, idąc za sentencją starszych autorów, powrołujących się na słynnego Sancheza, iż dla ważnego zawarcia małżeństwa wystarcza rozeznanie" quae in materia lethalis culpae sufficeret". Dopiero w r. 1920 przeciwstawił się tej zasadzie ówczesny Dziekan Roty Prior w wyroku z 27.7.1029 r., którego poparli współwotanci, audytorzy: X Florczak i Manucci; oni to uzasadnili, że do zawarcia małżeństwa konieczny jest wyższy poziom duchowy, ponieważ pożycie małżeńskie nakłada na kontrahenta zobowiązania trudne i dożywotne. Nie ma na całym świecie żadnej umowy, która miałaby dla okresu całego życia ludzkiego tak wielkie znaczenie jak właśnie kontrakt małżeński (Oesterle l.c.s. 201). Odtąd wspomniana wyżej zasada została przez św. Rotę zaniechana i od tego czasu żąda się od kontrahenta wyższego stopnia rozeznania aniżeli talkiego, które wystarcza do popelnienia grzechu śmiertelnego.

Przy tym należy mieć na uwadze, jak to Rota Rzym. w wyroku $z$ 30.4.1935 r. podała, że nie przesądza b raku dostatecznego rozeznania dla ważnego zawarcia małżeństwa okolicz- 
ność, że obciążony chorobą umysłową kontrahent dobrze sprawuje obowiązki swego urzędu; a to dlatego ponieważ może je sprawować W sposób raczej „materialny” czyli mechaniczny, a nie "modo humano". Rota zaznaczyła: ,apud peritos notum est, tales infirmos posse regulas artis, quas didicerunt etiam tempore insaniae sequi et applicare" (Oesterle 1.c.s. 301).

Zależy więc wszystko ostatecznie od wyrobienia sobie przez Trybunał przekonania na podstawie całokształtu materiału dowodowego o stanie sprawy. Sąd powinien dojść do moralnej pewności, czy dostarczono dowodu wystarczającego, czy też nie.

Może warto wspomnieć, że spośród chorób umysłowych tzw. $\mathrm{sch}$ i z ofrenia jest najczęściej zachodzącym rodzajem choroby umysłowej. Kanonista Oesterle O.S.B. (1.c.s. 284 n.) podaje, że w wyrokach Roty Rzym. w latach 1909-1914 rozpatrzono 67 wypadków amencji, a z tego 26 wypadków schizofrenii. $Z$ tych 67 wypadków ukończono 30 wyrokiem: constare de nullitate; a spośród 26 wypadków schizofrenii otrzymało 17: constare; a więc $2 / 3$.

Dawniejsze prawo przedkodeksowe wogóle nie wymagało $w$ procesach $z$ tytułu amencji orzeczeń lekarzy-biegłych (Dec. Rot. z 27.6.1916 r. nr 12). Dop i e ro Kodeks odstapif od tej zasady i zarządził $w$ can. 1982:... requiritur suffragium peritorum, qui infirmum, si casus ferat, eiusque acta examinent. Tak samo Instrukcja S.C.S. z 15.8 .1936 r. w art. 139 i 151 tego się domaga.

Reasumując powyższe uwagi w przedmiocie zasad normujących procedurę $\mathrm{w}$ sprawach o nieważność małżenstwa $\mathrm{z}$ tytułu amencji, dochodzimy do wniosku, że w razie niemożności poddania strony ekspertyzie lekarskiej oraz odmówienia złożenia zeznania przed Sądem Duchownym nie jest wykluczona możliwość przeprowadzenia procesu aż do wydania wyroku ewent. pozytywnego. Możliwość ta istnieje, jeżeli można przesłuchać w charakierze świadków lekarza wzgl. lekarzy, którzy leczyli stronę, oraz zebrać material dowodowy z zeznań strony powodowej i świadków. Tak przygotowany material dowodowy należy przedłożyć lekarzowi wzgl. dwom lekarzom-biegłym. Przewód sądowy w taki sposób przeprowadzony dostarczy 
w niejednym wypadku sędziemu duchownemu dostatecznej podstawy faktycznej dla wydania wyroku pozytywnego.

II.

Pozostaje do omówienia drugi wypadek, wymieniony $w$ tytule niniejsźego wykładu, mianowicie jaką zastosować procedure, gdy proces toczy się z tytułu impotencji, a strona nie chce złożyć zeznania i poddać się ekspertyzie lekarskiej.

$\mathrm{Na}$ marginesie sprawy warto zaznaczyć, że mamy deklarację św. Officium z 12.6.1942 r. opiewającą: ,omitti potest inspectio (mulieris) si, attenta partium et testium excellentia morali, ac serio pensatis eorum animi dispositionibus necnon ceteris adminiculis aut argumentis, Ordinarii iudicio, plenissima iam habeatur probatio de impotentia vel de inconsummatione". (AAS 1942 s. 201). Lecz to jest wypadek wyjątkowy z tym, że odnośna strona nie odmawia zlożenia zeznania sądowego.

Co do sprecyzowania pojęcia impotencji f u n k c jon a l nej oraz organiczne j odnośnie mężczyzny mamy magistralne określenie podane $\mathrm{w}$ wyroku Roty Rzym. $z$ dnia 30.6.1944 r. cor. Wynen (Dec. Rot. r. 1944 dec. 42 nr 3) następującej tresci: „Impotentia organic a seu instrumentalis in viro habetur si defectus physicus seu anatomicus adsit in eius organis copulatoriis, sine quibus vir censeri nequeat per se aptus ad procreandum; sive igitur vir aut nullum membrum virile aut membrum nimis exiguum et infantile habeat, sive careat utroque testiculo aut laboret impervietate epididymorum vel canaliculorum deferentium: in unoquoque casu vir est impotens ad perficiendam copulam perfectam, id est ad penetrandum in vaginam fermineam et ad verum semen in testiculis elaboratum, intra eandem vaginam effundendum".

Dalej wyjaśnia ten sam wyrok (1. c.): „Impotentia e contra functionalis oritur plerumque ex vitio systematis nervorum vel ex causis mere psychologicis, quae impediant quominus organa, per se apta, neque ullo modo laesa aut anatomice deficientia, functionem naturalem copulae perficere valeant; unde fit ut vir vel careat membri erectione sive totali sive sufficien- 
ti ad penetrandum, vel ut semen effundere nequeat intra vaginam. Iuxta diversam originem praedominantem huius impotentiae distingui solent variae species huius status morbosi, scl. impotentia vocatur vel nervosa, vel neurasthenica, vel psychica, vel simpliciter sexualis". Oraz dodaje ten sam wyrok:...

Co do impotencjikobiety podaje św. Rota w wyroku z dnia 9.1.1943 r. cor. Heard. (Dec, Rot. r. 1943 dec. 1 n. 2) definicję następującą: ,Impotens ergo est mulier $1^{0}$ si vagina caret, $2^{0}$ si eam omnino habet occlusam seu impenetrabilem, $3^{0}$ si nimis arctam sive absolute sive relative, $4^{0}$ si laborat vaginismo i. e. hyperestesia vulvae quae contactu viri tolerare nequit”. I dodaje: "Ad impedimentum autem canonicum constituendum necesse est ut defectus insanabilis sit, seu qui auferri nequit sine vitae discrimine vel gravi salutis detrimento".

Wracając do rzeczy zaznaczyć wypada, że inaczej rzecz się

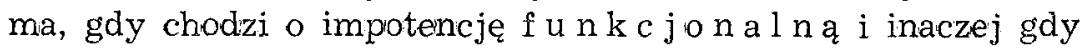
chodzi o impotencje organiczną (instrumentalis).

Kanonista Oesterle O.S.B. (Ephemerides Iur. Can. 1955 II. s. 154) stwierdza, że niektórzy autorzy saz zdania, że nigdy nie można udowodnić, by impotencja funkcjonalna (psychiczna), była trwała (nieuleczalna). - Dopiero wtedy istniałaby solidna podstawa do przyjęcia, że funkcjonalna impotencja jest nieuleczalna (perpetua), jeśli ma powiązanie z or g a n i c zn y $m$ defektem danej osoby (Oesterle 1.c.s. 154. zob. Dec. Rot. r. 1940 dec. 13. nr. 3).

Rota Rzymska w wyrokach swych często wyraża zdanie, że udowodnienie, iż impotencja funkcjonalna jest nieuleczalna (perpetua), jest rzeczą trudną: ,admodum difficile est admittere eam perpetuam", a to dlatego, że: ,adhibitis opportunis mediis curari potest", albo też z tego powodu że "de non cessatiosatione" non existit ,certum fundamentum" (Dec. Rot. 1942 dec. 38 nr 4). Sw. Rota przyjmuje tu zdanie autorów uznanych. jak Cappello, Wernz-Vidal, Chelodi, Sipos; Vidal zwięźle podaje: ,impotentia quando est functional is difficulter potest probari perpetua". 
Inaczej ma się rzecz, jeżeli impotencja funkcjonalna jest tylko względna (relativa); wtedy sądzą niektórzy autorzy, powiada Oesterle (1.c.s. 153), że nieuleczalność jej może być łatwiej udowodniona, ponieważ tutaj skierowuje się impotencja w kierunku tylko jednej osoby. Wtedy bowiem przyczyny duchowych hamulców, które udaremnily spełnienie pierwszegc aktu małżeńskiego, nie ustępują przy następnych próbach drokonania tego aktu; przeciwnie, nawet się wzmagają. Uczucie miłości, będące motorem stosunków małżeńskich, stopniowo przemienia się $w$ oziębłość, następnie $w$ odrazę i nawet w nienawiść, a tym samym zanika na stałe pożądanie dopełnienia aktów małżeńskich. (Dec. Rot. $\mathrm{z}$ dn. 5.4.1937 cor. Grazoli, zob. Oesterle l.c.s. 153). Jednak zasada ta nie da się podtrzymać wobec decyzji Roty Rzym. z d. 14.11 .1947 cor. D. Staffa, zawartej w XXXIX tomie Decisiones Rotae Rom. z r. 1947 (nr. 5 str. 540). Wyrok opiewa: „Doctrina vero et iurisprudentia nostra impotentiam functionalem vel psychicam, etsi relativam, natura et in genere perpetuam non putant: cum habitus corporis nerveus aut psychicus mutationibus etiam repentinis obnoxius sit, vel vi naturae, vel ope artis medicae, quae in dies progreditur". (Cor. Manucci, d. 4 mai 1934, Decisiones S. R. Rotae, vol XXVI, p. 270, n. 2); ita ferunt eg. methodum psychoanaliticam in his casibus haud inutiliter adhiberi. (cfr. Dalbiez, La méthode psychoanalitique et la doctrine freudienne, Paris 1936, II, p. 434)".

Może interesująca okolicznością co do h istorii badań tej rzeczy, jest fakt- co Rota w wyroku z 28.2.1942 cor. Canestri (Dec. Rot. dec. 12. nr 4) podaje - mianowicie: „quondam per congressum, id est tentatam copulam coram medico, notario ac matronis, veteres impotentiam comperiri praesumebant; itemque ad dignoscendam capacitatem erectionis recurrebant ad balneos calidos, confricationes membri, excitationes electricas et similia". I dodaje Rota: "Quae omnia quam inepta fuerint, nemo est qui non videat". (l.c.s. 113). W c z a s a ch wspólczesnych, powiada Rota, badanie przeprowadza się $\mathrm{w}$ tym przedmiocie za pomocą: egzaminu antropo- psychologicznego danego osobnika. Bada się więc formację anatomicz- 
ną całego organizmu, a w szczególności organów rodnych, tak zewnętrznych jak wewnętrznych; aktywność i mechanizm fizjologiczny tych organów oraz - co rzeczą jest trudniejszą -- bada się oblicze psychiczne danego indiwiduum. A więc bada się: jego inteligencję, wolę, pobudliwość, zmysły uczuciowe, seksualne i. t. p. $\mathrm{Naj}$ c z ęs c i e j powiada wsp. wyrok Roty wy pada prognoza, że dana impotencja jest czasowa (temporanea), ponieważ wystarcza, ażeby raz zostały przezwyciężone trudności hamujące, by stosunek mógł być wznowiony ,recte vel fere recte".

Schorzenia centrów nerwowych mózgowych - wyjaśnia Rota (w tym samym wyroku) - naruszające tzw. centrum wzwodu Goltz (centrum erectionis Goltz); oraz choroby umyslowe (morbi mentales) jak paraliż, niemniej alkoholizm, morfinizm, kokainizm, nadużycie kofeiny, nikotyny itp.; nastẹpnie infantylizm; ogólne schorzenia, jak febry,diabetes itp. także onanizm, mogą być przyczynami, lecz często c z ę ś c i o w y mi i niepewny mi, impotencji funkcjonalnej (Dec. Rot. l.c. s. 113).

To też stwierdzenie nieuleczalności impotencji f un k cjon a lne j napotyka na wielkie trudności, a domniemanie przemawia na korzyśc istnienia potentiae coe undi (Dec. Rot. 1.c. r. 1942 s. 114) i to tak u mężczyzny jak u niewiasty.

W wyroku z dnia 25.2.1941. cor. Wynen (Dec. Rot. 1941 dec. 13. nr. 4) wprost powiada św. Rota, że jeśli chodzi o impotentiam functionalem vel mere psychiacam, to nietylko lekarze i biegli często nie są pewni (ancipites haerent), czy $w$ danym wypadku zachodzi nieuleczalność impotencji, lecz nierzadko zdarza się, że impotencja ogłoszona jako nieuleczalna, przestaje istnieć bądź to ustępując $z$ biegiem czasu, bądź na skutek stosowania lekarstw i zabiegów. Stąd orzeczenie nieuleczalności impotencji funkcjonalnej przez lekarzy-biegłych jest zwykle problematyczne, według zdania św. Roty.

Znamienna jest wymowa wyroków Roty Rzymski e j co do wyników procesów odnośnie impotencji. 
Decisiones Rotae Romanae podające wyroki od r. 1946 wstecz do 1942 , a więc w pięciu rocznikach, podają 55 wyroków dotyczących impotencji. $Z$ tego przypadają na impotencję $f \mathrm{unk}$ c jonalną: 34 wyroki i to odnośnie impotencji mężczyzn 25, a odnośnie kobiet 9.

$\mathrm{Z}$ tych wyroków przypada co do mężc z y z n z wynikiem constat: 3, a $z$ wynikiem non constat: 22 ; co do kobie t $z$ wynikiem constat: 1 , a $z$ wynikiem non constat 8 . Natomiast co do impotencji or g a nicznej podają te 5 tomów Decisiones Rotae; 21 wyroków. $Z$ tych dotyczące impotencji mężczyzn 15, a kobiet 6 . Otóż z 15 wyroków odnośnie mężczyzn wydano $z$ wynikiem constat: 9, a $z$ wynikiem non constat 6 ; odnośnie impotencji organicznej kobiet 6 wspomnianych wyroków miało wynik: non constat.

Uwidocznia się $z$ tej statystyki już czysto zewnętrznie fakt, że udowodnienie impotencji funcjonalnej jest rzeczą trudną, co - jak poprzednio wspomniałem - często Rota Rzymska zaznaczała w swych wyrokach.

Co do metody udawadniania impotencji funcjonalnej podaje wyrok św. Roty z dnia 30.6.1944 cor. Wynen (Dec. Rot. 1944 dec. $42 \mathrm{nr}$. 5) następująca $\mathrm{m}$ a $\mathrm{g}$ is $\mathrm{tr}$ a $\mathrm{ln}$ ą zasadę: „si agatur de impotentia functionali saepe neque ex acuratissima inspectione et inquisitione quidquam pro existantia assertae impotentiae desumi potest, sed votum peritorum nititur quasi exclusive anamnesi, id est dictis ipsius viri inspecti qui est pars in causa". Jeśli jednak niekiedy lekarze-biegli, - powiada dalej Rota, - mogą wywnioskować $\mathrm{z}$ obiektywnych danych (ex obiectivis signis), że dany mężczyzna nie ma "funcionem activitatis generativae", wtedy mogą dać orzeczenie pewne tylko o aktualnym stanie badanego; jednak nie zawsze mogą biegli stwierdzić z moralną pewnością, że aktualnie istniejąca impotencja była poprzedzająca małżeństwo (antecedens), oraz tylko bardzo rzadko (rarissime) orzec mogą, że jest nieuleczalną, czyli trwałą (perpetua). Doświadczenie lekarskie i sądownicze wykazuje, powiada Rota, że impotencja funkcjonalna może być uzdrowiona "mero decursu temporis vel aptis curis adhibitis". 
Należy porównać powiada Rota (Dec. Rot. 1944 dec. 14 nr. 9 cor. Teodori $\mathrm{z}$ d. 6. 3. 1944) zeznania stron $z$ orzeczeniami lekarzy-biegłych i jeśli wykaże się, że anamneza, przeprowadzona przez lekarzy, zgadza się $\mathrm{w}$ sprawach istotnych $z$ rzeczywistościa faktów, oraz mając na uwadze fenomeny fizyczne, stwierdzone przez samych lekarzy, wtedy można dojść do moralnej pewności o istnieniu impotencji funcjonalnej, która jest antecedens et perpetua.

W trzech wyrokach Roty pozytyw n y h, o czym wyżej wspomniałem, orzekających nieważność mażeństwa $z$ tytułu impotencji funkcjonalnej pozwanego mężczyzny (Dec. Rot. r. 1944 , dec. 14 oraz 65 i r. 1945 dec. 48) materiał dowodowy zawierał zawsze: zeznania stron i świadków oraz ekspertyzę lekarzy-biegłych. Tak samo było w jedynym jednym wyroku pozytywnym dotyczącym niewiasty (Dec. Rot. 1944 dec. 39), z pośród dziewięciu które Rota podała.

Zaznaczyć wypada, że mamy wyrok św. Roty, w którym pozwany $z$ tytułu impotencji funkcjonalnej mężczyzna nie był poddany ekspertyzie przez lekarzy-biegłych, z powodu odmowy, jednak złożył zeznanie przed sądem. (Dec. Rot. 1942 dec. 38 cor. Teodori). Wyrok zapadk: non constat de nullitate matrimonii. Lekarze-biegli byli czynni w procesie, lecz niczego innego nie mogli dokonać, jak tylko: relationem super a ctis tradere. Trybunał św. Roty. wywnioskował $\mathrm{z}$ materiału dowodowego, że wprawdzie zachodzi impotentia antecedens, functionalis psychica, relativa (in viro); lecz nie mógł usunąć dubium positivum et grave co do nieuleczalności impotencji, ponieważ uzasadnienie tej okoliczności przez lekarzy biegłych było niedostateczne.

W tym wyroku Rota podaje ważną zasadę; mianowicie powiada: ;quando periti iuspectionem corporalem quacumque de causa non peregerunt, et relationem dederunt solummodo actis innixi, ,requiritur ut periti circa rem de qua referunt plene sint infurmati". (Dcc. Rot. 1. c. nr. 5.

W tej zasadzie jasno św. Rota stwierdza, - przynajmniej teoretycznie, - że bez poddania odnośnej strony ekspertyzie przez lekarzy-biegłych, gdy to nie jest możliwe n.p. dlatego 
że strona się wzbrania, można jednak przeprowadzić proces $\mathrm{kanoniczny.} \mathrm{Lekarze-biegli} \mathrm{mieliby} \mathrm{w} \mathrm{takim} \mathrm{wypadku} \mathrm{to}$ zadanie, by wydać swe orzeczenie na podstawie materiału dowodowego zawartego $w$ aktach sprawy; materiał ten polegałby na zeznaniu strony powodowej ewent. i pozwanej, jeśli nie odmówiła złożyć zeznania, oraz świadków i ewent. na zaświadczeniach i zeznaniach lekarzy, którzy ewent. prywatnie leczyli daną stronę. - Czy na takiej podstawie byłby możliwy wyrok pozytywny?

Sądząc po wynikach wyroków Roty Rzymskiej przemawia za tym mało prawdopodobieństwa, ponieważ $\mathrm{w}$ wyżej wymienionych rocznikach tych wyroków żądnego tego rodzaju pozytywnego wyroku, gdy chodzi o impotencję funkcjo$\mathrm{n}$ a l $\mathrm{n}$ ą, nie podano. Tym więcej nie byłoby to prawdopodobne, gdyby odnośna strona nietylko nie poddała się ekspertyzie lekarskiej, lecz nawet wzbraniała się zlożyć zeznanie sądowe.

Lecz in n e jest w y j śc i e w takiej sytuacji. Choć przewód sądowy dla braku zeznania odnośnej strony i z powodu nie poddania się jej ekspertyzie lekarskiej, nie mógł stwierdzić nieważności małżeństwa z tytułu impotencji funkcjonalnej, jednak dość często istnieje $w$ takich razach możliwość stwierdzenia niedopełnienia małżeństwa; wtedy można wnieść prośbę do Ojca śx. o udzielenie dyspensy od małzeństwa niedopełnionego. W 34 procesach z tytułu impot. funkcjonalnej, podanych w poprzednio wspomnianych rocznikach (25 odnośnie impot. mężczyzn i 9 odnośnie impot. kobiet) w 17 wypadkach (13 odnośnie mężczyzn i 4 odn. "kobiet) uzyskano dowód na okoliczność niedopełnienia małżeństwa i Rota wydała orzeczenie koncowe: consilium prastandum est Sanctissimo pro dispensatione super matrimonio rato sed non consummato.

Gdy chodzi o drugi rodzaj impotencji, mianowicie o impotencję organiczną (organica, instrumentalis), rzecz ma się nieco prościej.

Co do metody udowodnienia tej impotencji wypowiedziała św. Rota zasadę: „probationem impedimenti impotentiae quod spectat, nulla habeturspecialis difficultas si agatur de impotentia org a nic a.." (Dec. Rot. 1944 dec. 42 cor. Wynen $\mathrm{nr}^{\circ}$ ). 
Impotencja organic zna uwidacznia się łatwiej na zewnątrz i jest łatwiej dostrzegalna. Słusznie powiada autor Adalbertus Van Duin (Apollinaris $1950 \mathrm{nr} .1 / 2 \mathrm{~s}$. 123) "generice dicitur impotentiam organicam provenire ex vitio anatomico; huiusmodi defectum esse spectabilem, f a cilius ma nifestu m". Impotencja organiczna uwidacznia się łatwiej na zewnątrz i jest latwiej dostrzegalna.

Oczywiście, jeśl dane vitium anatomicum, quod afficit ipsum apparatum genitalem, sensibus corporeis percipi potest, natenczas istniałaby $w$ niektórych wypadkach możliwość nawet bez przeprowadzenia oględzin przez lekarzy-biegłych i bez zeznania sądowego danego osobnika przeprowadzenia dowodu na istnienie impotencji, skoro istniałyby odnośnie tej sprawy zeznania strony powodowej i wiarogodnych świadków. Chodziłoby więc o tego rodzaju vitia anatomica u mężczyzny, jak absentia totalis membri, absentia utriusque testiculi (t. zw. anorchidia), jednak $z$ tym zastrzeżeniem, że nie zachodzi tylko wr oś $\mathrm{n}$ i ę c i e jąder w pachwinę (cryptorchidia; testes latent in abdomide vel in canali inquinali), co - jak wiadomo nie zawsze powoduje impotencji. Ten ostatni wypadek nie mógłby się odbyć bez orzeczenia lekarzy, którzy występowali przynajmniej jako świadkowie.

W tych wypadkach mogą być świadkowie, którzy z autopsji sa $W$ stanie zeznawać o wyżej podanych okolicznościach. Rzeczywiście istnieje wyrok Roty (Dec. Rot. 1943 dec. 62 cor. Wynen, z d. 28.7.1943) orzekający nieważność malżeństwa z tytułu impotencji or g a n i c z ne j pozwanego mężczyzny, mimo że odmówił założenia zeznania przed sądem oraz nie poddał się oględzinom lekarskim przez lekarzy-biegłych. Jedyne, co $w$ przewodzie sądowym uzyskano od pozwanego, było jego prywatne wypowiedzenie się do duszpasterza, skłaniającego go do złożenia zeznania sądowego i poddania się ekspertyzie, w zdawkowym zdaniu: przecież powódka wiedziała, że jestem impotentem, gdy decydowała się mnie poślubić. Materiał dowodowy dla pozytywnego wyroku $\mathrm{w}$ niniejszej sprawie polegal na naistępujących danych: byly zgodne zeznania dwóch naocznych świadków, którzy oglądali organizm pozwanego przy 
okazji poboru wojskowego, w którym sami brali udzial; Prócz tego była $\mathrm{w}$ aktach sprawy peritia extraiudicialis lekarza, który prywatnie przed wniesieniem skargi przeprowadził oględziny pozwanego. Następnie było w aktach autentyczne świadectwo władzy ' wojskowej, poświadczające impotentiam "tamquam evidens". Tak zestawiony materiał dowodowy uznała św. Rota za wystarczający i wydała wyrok pozytywny jako ostateczny, podlegający wykonaniu.

Istnieje więc możliwość w niektórych wypadkach, gdy zachodzi impotencja or g a n i c z n a, przeprowadzenia procesu kanonicznego i doprowadzenia do wyroku pozytywnego nawet wtedy, gdy pozwrany odmawia złożyć zeznanie sądowe i nie chce poddać się oględzinom lekarskim. Niewątpliwie będą to wypadki raczej nieliczne i wyjątkowe, a więc gdy impotencja polegać będzie na absentia evoluti membri et utrisque testiculi $\mathrm{z}$ zastrzeżeniem wyżej wypowiedzianym. Lecz w innych wypadkach $n p . w$ razie: impervietatis epidymorum vel canalium deferentium bez ekspertyzy lekarskiej wydanie wyroku pozytwnego na ogół nie byłoby możliwe. Teoretycznie i $w$ takich wypadkach możliwość taka mogłaby istnieć, gdyby istniały $w$ aktach orzeczenia lekarzy świadków, którzy danego osobnika badali przed lub krótko po ślubie, jeśli u nich szukał porady lekarskiej. Te orzeczenia należałoby przedłożyć razem z całym materiałem dowodowym lekarzom - biegłym do zaopiniowania. Zawsze jednak rozważyć by należało, czy istnieje możliwość udowodnienia faktu niedopełnienia małżeństwa i uzyskanie dyspensy papieskiej od małżeństwa niedopełnionego.

W wyżej wspomnianych pięciu rocznikach wyroków Roty nie podano ani jednego wypadku, $w$ którym przy przeprowadzeniu procesu $z$ tytułu impotencji organicznej mężczyzny $z$ wynikiem negatywnym (non constat) Trybunał Roty zakończyłby orzeczenie decyzją: consulendum esse Sanctissimo pro dispensatione super matrimonio non consummato.

Co do impotencji o r g a n i c z ne j k o b i e ty, to bez ekspertyzy lekarzy-biegłych dowodu impotencji n a o g ó 1 przeprowadzić by nie można. Chyba że można by uzyskać zeznania leka- 
rzy, którzy ewnt. leczyli daną osobe przed lub po ślubie. Zeznania te razem $\mathrm{z}$ całym materiałem dowodowym należałoby przedstawić lekarzom - biegłym do wydania votum.

Posiadamy wyrok Roty z 23.12.1941. (Dec. Rot. 1914 dec. 99 cor. Canestri s. $956 \mathrm{n}$ ), który wydał orzeczenie $\mathrm{z}$ tytułu impotencji organicznej kobiety pozytywne (constat), mimo że lekarze biegli nie przeprowadzili ekspertyzy. W materiale dowodowym znajdowało się jednak kilka zeznań lekarek, w tym dwa zeznania zaprzysiężone lekarek, które przeprowadziły $z$ rozkazu Ordynariusza badania pozwanej, lecz p r zed rozpoczęciem procesu; - rzecz działa się na terenach misyjnych w Afryce (Tanganica). Wyrok Roty opiewa, że can. 1976 nakazuje wprawdzie przeprowadzenie inspectionis corporis, jednak dodaje: „nisi ex adiunctis inutilis evidenter appareat”. Otóż w tym wypadku uznała Rota ekspertyzę lekarzy-biegłych za zbyteczną wobec zawartych $w$ aktach kilku inspectiones extraiudiciales pozwanej, a także mając na oku trudności wynikające $z$ rozległości terenów misyjnych. Znamiennym jest także i ten szczegół, że prócz stron nie przesłuchiwano świadków np. krewnych stron, a to raz dlatego, że byli poganami, nieprzychylnie nastawionymi do tego procesu małżeńskiego ich krewnej; oraz powtóre dlatego, że praktycznie byli trudno osiągalni na tamtejszych rozległych terenach. Lekarzy-biegłych w tym procesie Rota wogóle nie przywołała.

W procesach $z$ tytułu impotencji organicznej kobiety, które Rota podaje w latach 1942 - 1946 znajduje się 6 wyroków negatywnych, a ani jeden pozytywny. W trzech wyrokach kończy się orzeczenie decyzją, by zwrócić się do Ojca sw. o udzielenie dyspensy od małżeństwa niedopełnionego.

Zawsze więc należy rozważać w wypadkach, w których, czy to dla braku zeznania strony, wzbraniającej się złożyć zeznanie, i wzbraniającej się poddać ekspertyzie lekarskiej, czy wogóle dla braku dowodów, nie można stwierdzić istnienia impotencji poprzedzającej zawarcie małżeństwa oraz jej nieuleczalności, czy nie istnieje możliwość udowodnienia faktu ni edopełniania małżeństwa i wszczęcia postępowania o uzyskanie dyspensy papieskiej od małżeństwa niedopełnionego. (zob. Dec. Rotae. 1942, dec. 38 nr. 6). 